\title{
NOTE
}

\section{Digestion of copepod eggs by larval turbot Scophthalmus maximus and egg viability following gut passage}

\author{
D. V. P. Conway, I. R. B. McFadzen, P. R. G. Tranter
}

Natural Environment Research Council, Plymouth Marine Laboratory, Prospect Place, West Hoe, Plymouth, Devon PL1 3DH, United Kingdom

\begin{abstract}
Between 20.5 and $93.6 \%$ of the subitaneous eggs of 6 species of egg-carrying copepods passed undigested through the digestive tracts of larval and early postlarval turbot Scophthalmus maximus. Viability of the eggs of Eurytemora affinis, E. velox and Euterpina acutifrons remained high on egestion (67.0 to $91.7 \%$ ), Pseudocalanus elongatus and Oncaea venusta eggs had low viability 1.1 to $1.5 \%$ ), while all Corycaeus anglicus eggs were rendered inviable. The indigestibility of the eggs denies the turbot larvae a potentially valuable food resource, while retention of high egg viability in certain species reduces the effect of predation.
\end{abstract}

KEY WORDS: Scophthalmus maximus larvae - Copepod eggs Digestion - Egg viability

Organisms consumed when larval and early post-larval turbot Scophthalmus maximus are fed on mixed zooplankton vary in their digestibility (Conway et al. 1993). Of particular note, copepod eggs appear to remain completely undigested. This has important nutritional implications, as numerically, eggs can form a substantial proportion of the diet of larval fish (e.g. Conway 1980 , Kellerman 1990). Resistance to digestion by copepod eggs has previously been indicated from gut content studies, where apparently undigested eggs, of a range of species, have been observed in the digestive tracts of the larvae of herring Clupea harengus (Schnack 1972), grey mullet Mugil spp. (Zismann et al. 1975), blue whiting Micromesistius poutassou (Conway 1980), Japanese sardine Sardinops melanostictus (Nakata 1988), rockling Ciliata spp. (Tully \& O Céidigh 1989) and anchovy Engraulis anchoita (Viñas 1991). Since these observations were on eggs still on passage through the intestinal tract, it cannot be discounted that they had recently been ingested. However, gut content observations can indicate whether there is differential digestion between food items, and this was indeed noted during a study on feeding of larval sprat Sprattus sprattus (Conway et al. 1991). In that study female copepods of Pseudocalanus elongatus and Oithona sp., both egg-carrying species, were found in the hind-guts well digested with only their exoskeletons remaining, while eggs in close association, presumably from the copepods, were undigested (Conway unpubl.). A similar differential digestion of copepod females and eggs has also been noted during gut content examination of the chaetognath Sagitta elegans (Alvarez-Cadena 1993).

Resistance to digestion of a range of crustacean eggs has been confirmed from faecal examination of several groups. Faeces of the shore bird Charadrius vociferus contained a selection of freshwater crustacean (anostracan, copepod and ostracod) eggs (Proctor et al. 1967 ) and some were still viable. Copepod eggs, both subitaneous and diapause, were isolated from the faeces of marine benthic polychaetes and a high proportion were viable (Marcus 1984). Non-digestion of subitaneous copepod eggs has been further demonstrated by the work of Crawford \& Daborn (1986), who found that when adults of a small estuarine fish Menidia menidia fed on egg-carrying females of the brackish water, estuarine copepod Eurytemora herdmanni, many intact eggs were egested. Reddern \& Daborn (1991), using the same 2 species, established that $90 \%$ of egested copepod eggs were viable.

The above, largely qualitative experiments, were all carried out on adult animals from either fresh water or estuarine/coastal marine environments. The crustacean eggs fed upon were either diapause, or from species which can produce diapause eggs, so the eggs may be particularly adapted to survive environmental stress. This study is the first to investigate the ability of a larval fish species, the turbot, to digest the subitaneous eggs of a selection of egg-carrying copepod species of both estuarine/coastal and open sea distrib- 
utions, including species which are only known to produce subitaneous eggs. Turbot larvae are particularly suited to this type of study as they package their faeces in a thin membrane (Conway et al. 1993), so output of faecal material can be monitored.

Material and methods. Studies were carried out at a commercial fish farm, Golden Sea Produce Ltd, Hunterston, Scotland, in February 1992 and at the Plymouth Marine Laboratory, Plymouth, England, in August 1992 and July and August 1993 using farmed turbot larvae aged 25 to $77 \mathrm{~d}$ post-hatch, length 6.8 to $36.3 \mathrm{~mm}$. Larval turbot commence metamorphosis at approximately $35 \mathrm{~d}$ post-hatch, but for convenience all specimens were termed larvae. Depending on larval size, groups of 3 to 10 were placed in 5 or $15 \mathrm{l}$ glass aquaria containing filtered $(20 \mu \mathrm{m})$ seawater (33 to $34.5 \mathrm{psu}$ ) collected in the open sea off Plymouth. They were maintained under conditions of continuous subdued lighting and gentle aeration at 16 to $19^{\circ} \mathrm{C}$. The water of the experimental aquaria was replaced at least every second day with fresh seawater at the same temperature and salinity.

Turbot larvae had been fed on brine shrimp Artemia salina nauplii at the fish farm, but this diet was replaced with live zooplankton, collected locally to Plymouth approximately 3 times a week using a variety of plankton nets ( 50 to $200 \mu \mathrm{m}$ ). In the experiments female copepods which carry their eggs rather than species laying free-spawned eggs were used, to encourage larvae to feed on large numbers of copepod eggs in a short time period and to allow more accurate assessment of throughput of eggs.

The calanoid copepod Pseudocalanus elongatus, the cyclopoids Oncaea venusta and Corycaeus anglicus and the harpacticoid Euterpina acutifrons were obtained from the zooplankton samples collected off Plymouth in a salinity of 33 to 34 psu. The calanoid copepod Eurytemora affinis was collected from the upper tidal River Tamar north of Plymouth in a salinity of 3 to 4 psu and Eurytemora velox obtained from Golden Sea Produce Ltd, where it was being cultured in a salinity of approximately 12 psu. Females of these copepods were extracted from samples and kept in beakers until they produced eggs. For each experiment a sub-sample of the female copepods was measured (total length), the number of attached eggs counted and egg diameter measured (see Table 1).

Only in Oncaea venusta and Corycaeus anglicus were the eggs clearly carried in sacs; the eggs in $O$. venusta were compressed to a sub-circular shape within the sac. Eurytemora affinis, E. velox, Pseudocalanus elongatus and Euterpina acutifrons carry their eggs in a single mass without any obvious outer egg sac. Apart from $P$. elongatus and $O$. venusta, all other experimental species have dark egg membranes.
Experiments were started at approximately 08:00 GMT following a $14 \mathrm{~h}$ overnight period when no further food was added, so food density decreased. The seawater in the aquaria was first replaced with fresh filtered seawater and the larvae allowed to acclimatize for $0.5 \mathrm{~h}$. All egg-carrying copepods of the species being examined were extracted from the beakers, transferred to the aquaria and the turbot larvae observed at intervals until they had ingested the copepods. Live, mainly copepod zooplankton was then introduced, so that movement of food through the digestive tract was encouraged. Plankton density was maintained at approximately 200 organisms $l^{-1}$. Experiments were conducted each day, so all copepod eggs consumed were aged 1 to $24 \mathrm{~h}$ post-laying.

Larval turbot produce faeces covered in a thin membrane, which maintains their structural integrity. To see how long it took for the membrane to break down, samples of intact faeces were incubated at $16^{\circ} \mathrm{C}$ in seawater. Faeces settle out immediately and are easily identifiable on the bottom of the aquaria as the membrane is usually orange or brown in colour. They were gently collected every 15 min using a large, wide-bore pipette, placed in solid watch glasses containing filtered seawater and dissected under a microscope. The time taken for the experimental copepods and their eggs to appear in the faeces (gut passage time) was recorded. To estimate whether any eggs were being lost through complete digestion, the number of female copepods and number of eggs associated with them in the faeces was noted and compared with the mean number of eggs being carried before they were fed to the larvae.

To check the viability of eggs in the faeces from the feeding experiments above, eggs were left in the watch glasses, while all other faecal remains and as much seawater as possible were removed with a fine pipette. Fresh, filtered seawater was then introduced and the watch glasses covered with glass slides to prevent evaporation. The eggs were incubated at $16^{\circ} \mathrm{C}$ in continuous subdued light. They were examined at regular intervals for up to $9 \mathrm{~d}$ and the appearance of nauplii used as a measure of viability. Their viability was compared with that from a control group of eggs which had not passed through turbot larvae.

The calanoid copepods Acartia clausii and Temora longicornis spawn subitaneous eggs freely into the water. During egg laying, small numbers of eggs ( 2 to 5) were observed to remain attached to the genital segment for some time before being dislodged by sudden movement of the female, or physical contact with other zooplankton. Eggs can thus be ingested incidentally by larval fish when feeding on the female copepod. Small numbers of their eggs were recovered from the faeces and incubated as above. 
To ascertain the condition of the larvae during the experiments small numbers were removed at intervals, anaesthetised using MS-222 and preserved in Baker's formol calcium fixative for histological examination. Following fixation, smaller larvae were processed for methacrylate embedding and sectioned at $2 \mu \mathrm{m}$ in the sagittal plane (McFadzen et al. in press). Larger larvae were processed for paraffin wax embedding, then serially sectioned at $5 \mu \mathrm{m}$ in the sagittal plane. All methacrylate sections were stained in Lee's methylene blue/basic fuchsin (Bennett et al. 1976) and wax sections in haematoxylin and eosin prior to examination for tissue condition.

Results. Between copepod species the number of eggs carried varied considerably (Table 1). Corycaeus anglicus had the greatest mean number of eggs $(38.0 \pm 14.46)$. Pseudocalanus elongatus the fewest $(8.3 \pm 2.69)$. Because female copepods were at different states of egg laying when examined, there was considerable variation in the number of eggs carried by individuals of the same species. In C. anglicus, Eurytemora affinis and $E$. velox, eggs were strongly attached to the females, while in $P$. elongatus especially but also in Oncaea venusta and Euterpina acutifrons, eggs were more readily detached from, or discarded by, the females.

It was noted that female Eurytemora velox containing ripe eggs in the oviducts sometimes transferred them to the egg mass when stressed, e.g. when they were transferred to a small petri dish for microscopic examination.
Eggs in the oviducts measured slightly less in diameter ( 73 to $82 \mu \mathrm{m}$ ) than those in the egg mass (90 to $110 \mu \mathrm{m}$ ), but were already circular in shape.

Hatching time of the fresh, control eggs was generally the value given at the lower end of the ranges in Table 1; only small numbers of eggs required the full number of days given. Viability was $>84.8 \%$ for all species except Euterpina acutifrons (68.6\%). Of all the individual batches of eggs of Eurytemora velox, Corycaeus anglicus and Oncaea venusta incubated, at least a proportion of each batch hatched. In Eurytemora affinis, Pseudocalanus elongatus and E. acutifrons there were respectively $5.7,8.7$ and $13.3 \%$ of individual copepod egg batches totally failing to hatch. The low egg viability in $E$. acutifrons resulted from a combination of high individual egg batch failure coupled with a general low hatch rate.

While food was not replenished overnight, the turbot larvae were not starved at any time, as live food was still present in the aquaria in the mornings. The initial faeces produced during the experiments were composed of food introduced the previous day. Examination of faecal material showed that while copepodites were digested to the extent that only exoskeletons remained, a proportion of the ingested eggs of all copepod species were present, apparently unaffected by digestion. The time taken for female copepods and their eggs to pass through the intestinal tract was variable (Fig. 1), ranging from 1.8 to $6.5 \mathrm{~h}$ (mean overall time $3.9 \pm 1.2 \mathrm{~h}$ ) and was not obviously related to larval

Table 1. Scophthalmus maximus. Mean lengths, egg diameter, number of eggs carried, hatching time and egg viability, fresh and after gut passage, for the 6 main copepod species fed to turbot larvae. SD given where possible

\begin{tabular}{|c|c|c|c|c|c|c|}
\hline & $\begin{array}{l}\text { Eurytemora } \\
\text { affinis }\end{array}$ & $\begin{array}{l}\text { Eurytemora } \\
\text { velox }\end{array}$ & $\begin{array}{l}\text { Pseudocalanus } \\
\text { elongatus }\end{array}$ & $\begin{array}{l}\text { Oncaea } \\
\text { venusta }\end{array}$ & $\begin{array}{l}\text { Corycaeus } \\
\text { anglicus }\end{array}$ & $\begin{array}{l}\text { Euterpina } \\
\text { acutifrons }\end{array}$ \\
\hline Range of total length ( $\mathrm{mm})$ & $1.07-1.29$ & $1.36-1.68$ & $1.00-1.18$ & $0.64-0.68$ & $0.86-1.07$ & $0.68-0.79$ \\
\hline Mean length & $1.19 \pm 0.06$ & $1.48 \pm 0.09$ & $1.08 \pm 0.05$ & $0.66 \pm 0.02$ & $0.96 \pm 0.06$ & $0.72 \pm 0.04$ \\
\hline No. of observations & 20 & 18 & 19 & 13 & 18 & 6 \\
\hline Range egg diameter $(\mu \mathrm{m})$ & $73-98$ & $90-110$ & $102-122$ & $45-57$ & $54-60$ & $54-73$ \\
\hline Mean egg diameter $(\mu \mathrm{m})$ & $85.5 \pm 5.50$ & $103 \pm 7.38$ & $116 \pm 7.04$ & $53 \pm 3.53$ & $57 \pm 2.02$ & $62 \pm 5.88$ \\
\hline Range no of eggs carried & $7-44$ & $3-23$ & $2-14$ & $13-34$ & $15-57$ & $9-20$ \\
\hline Mean no. of eggs carried & $21.8 \pm 9.97$ & $11.7 \pm 4.78$ & $8.3 \pm 2.69$ & $22.3 \pm 7.34$ & $38.0 \pm 14.46$ & $14.1 \pm 2.87$ \\
\hline No. of observations & 70 & 21 & 68 & 18 & 18 & 27 \\
\hline Hatch time (d) & $2-3$ & $2-4$ & $3-6$ & $2-6$ & $3-4$ & $2-3$ \\
\hline Viability of fresh eggs $(\%)$ & 89.4 & 95.4 & 84.8 & 87.1 & 85.7 & 68.6 \\
\hline No. of females & 63 & 11 & 29 & 18 & 18 & 27 \\
\hline Total no. of eggs in experiment & 1370 & 131 & 224 & 402 & 701 & 390 \\
\hline Viability of egested eggs $(\%)$ & 91.7 & 82.5 & 1.1 & 1.5 & 0 & 67 \\
\hline Total no of eggs in experiment & 1692 & 532 & 184 & 66 & 420 & 264 \\
\hline $\begin{array}{l}\text { Mean no. of eggs female }{ }^{-1} \\
\text { in faeces }\end{array}$ & 16.1 & 7.5 & 1.7 & - & 20 & 13.2 \\
\hline $\begin{array}{l}\text { Eggs passing through the gut } \\
\text { undigested }(\%)\end{array}$ & 73.9 & 64.1 & 20.5 & - & 52.6 & 93.6 \\
\hline Larval turbot age (d) & $32-72$ & $30-62$ & $35-74$ & $28-72$ & $26-60$ & $25-62$ \\
\hline
\end{tabular}


age. A small number of eggs ( $<1 \%$ ) had disrupted egg membranes which may have been due to digestive action, or possibly handling damage. In Eurytemora velox and Euterpina acutifrons the eggs tended to remain in a group, closely associated with the female copepod exoskeleton. In Eurytemora affinis, Pseudocalanus elongatus and Corycaeus anglicus, eggs were individually scattered through the faeces (Fig. 2a, b). In Oncaea venusta the eggs remained within the egg sacs although separated from the females.

A comparison of the mean number of eggs carried by live copepod females, with the mean number associated with female exoskeletons of the same species in the faeces, showed that there was a reduction in number on egestion for all species (Table 1). This reduction was variable between species. The percentage of Euterpina acutifrons eggs recovered after passing through the intestinal tract was $93.6 \%$, while that for Pseudocalanus elongatus was $20.5 \%$. Because Oncaea venusta did not always have paired egg sacs and as there were so few observations on this species, it was not possible to calculate the number of eggs per female in the faeces. Their egg sacs were not broken down by digestion, so it is possible that all their eggs could be recoverable from the faeces.

Viability of the eggs of Eurytemora affinis, E. velox and Euterpina acutifrons from faeces was similar to the

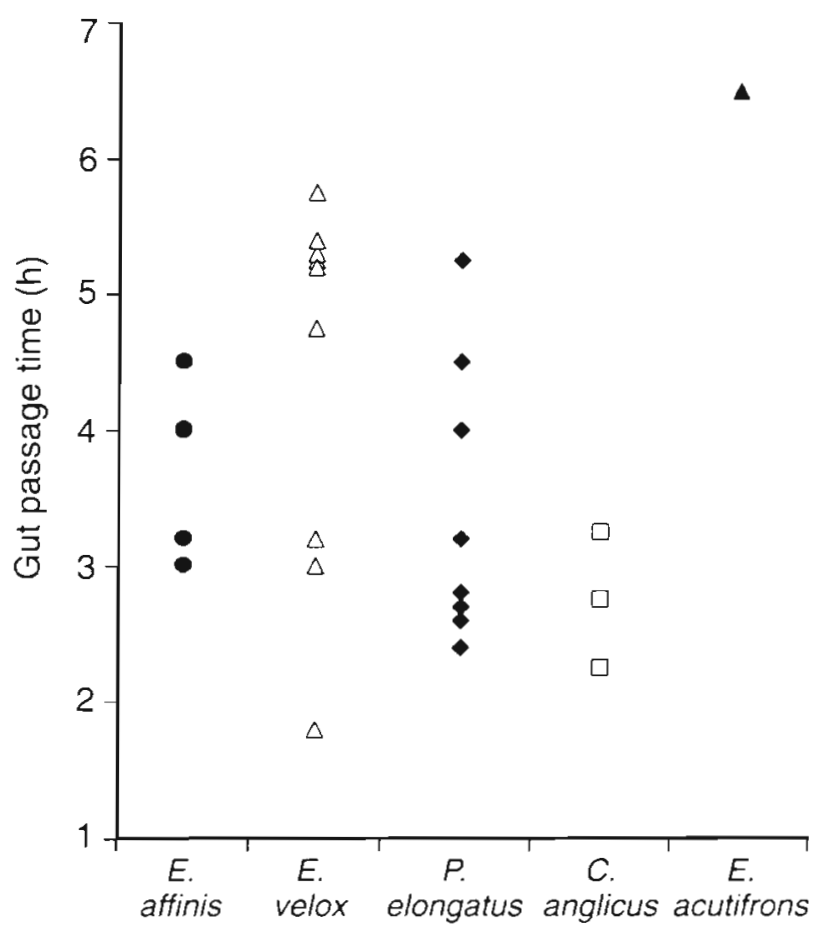

Fig. 1. Scophthalmus maximus. Time interval between feeding on egg-carrying copepods and time of eggs first appearing in the faeces of turbot larvae aged 23 to $76 \mathrm{~d}$, for 25 individual experiments viability of their fresh eggs. In contrast, the viability of egested eggs of Pseudocalanus elongatus and Oncaea venusta was reduced to 1.1 and $1.5 \%$ respectively, while all the eggs of Corycaeus anglicus were inviable

Small numbers of eggs of free-spawning copepod species were recovered from the faeces. Of 4 Temora longicornis eggs (80 to $82 \mu \mathrm{m}$ diameter) recovered, $50 \%$ hatched and of 9 Acartia clausil eggs ( 75 to $82 \mu \mathrm{m}$ diameter), $55 \%$ hatched.

It was difficult to make internal microscopic observations on eggs with dark egg membranes. Pseudocalanus elongatus egg membranes are clear and on egestion eggs had changed colour from pale golden to light orange and some contained globules of oil. In most cases cells could not be distinguished internally.

Faeces were left to decompose at $16^{\circ} \mathrm{C}$. After $3 \mathrm{~d}$, when ciliate numbers had built up, there was evidence of the membrane starting to be broken down. The faeces break off as they are produced so the faecal membrane does not usually cover the ends of the faeces. Nauplii hatching out from eggs located close to the ends were seen to escape from the open ends. However, other nauplii hatching out further within the faeces appeared to be trapped and dying there.

There was no suggestion that digestion was at any time impaired, as copepods in the faeces were reduced to exoskeletons and larvae grew continuaily and well. As confirmation of these observations, histological sections of whole larvae used in the egg viability trials demonstrated that the entire digestive tract and its associated glands (liver and pancreas) were in excellent condition. Large regular villi were present in the fore- and mid-gut regions, with masses of microvilli covering the luminal surface of the epithelium. All tissues were found to be healthy, in accordance with descriptions by McFadzen et al. (in press).

Discussion. It is clear from the present study that a substantial proportion of the eggs of all copepod species examined are not digested by larval turbot. Histological observations demonstrated that the experimental turbot larvae were in good condition, so digestion resistance of copepod eggs could not be attributed to degeneration of the intestinal lining, which can develop within a few days in turbot larvae, following periods of low food intake, or starvation (McFadzen et al. in press). Resistance to digestion was not because the eggs were the thick-walled diapause type which some copepods, including Eurytemora affinis (Ban \& Minoda 1991) and E. velox (Champeau 1970), produce in response to environmental stress. This was confirmed by the short hatching time of $<6 \mathrm{~d}$ in all species. There was also no suggestion that digestion of eggs was affected by variations in gut retention time. Euterpina acutifrons had the longest passage time $(6.5 \mathrm{~h})$, yet eggs were not digested and mean number of eggs 
Fig. 2. Scophthalmus maximus. Faecal pellets of turbot larvae containing (a) Eurytemora affinis eggs (29 d larvae), $\times 20$, and (b) Pseudocalanus elongatus eggs ( $\mathrm{P})$, Corycaeus anglicus eggs (C) and oil globules $(O)$ probably from $P$. elongatus (29 d larvae), $\times 50$
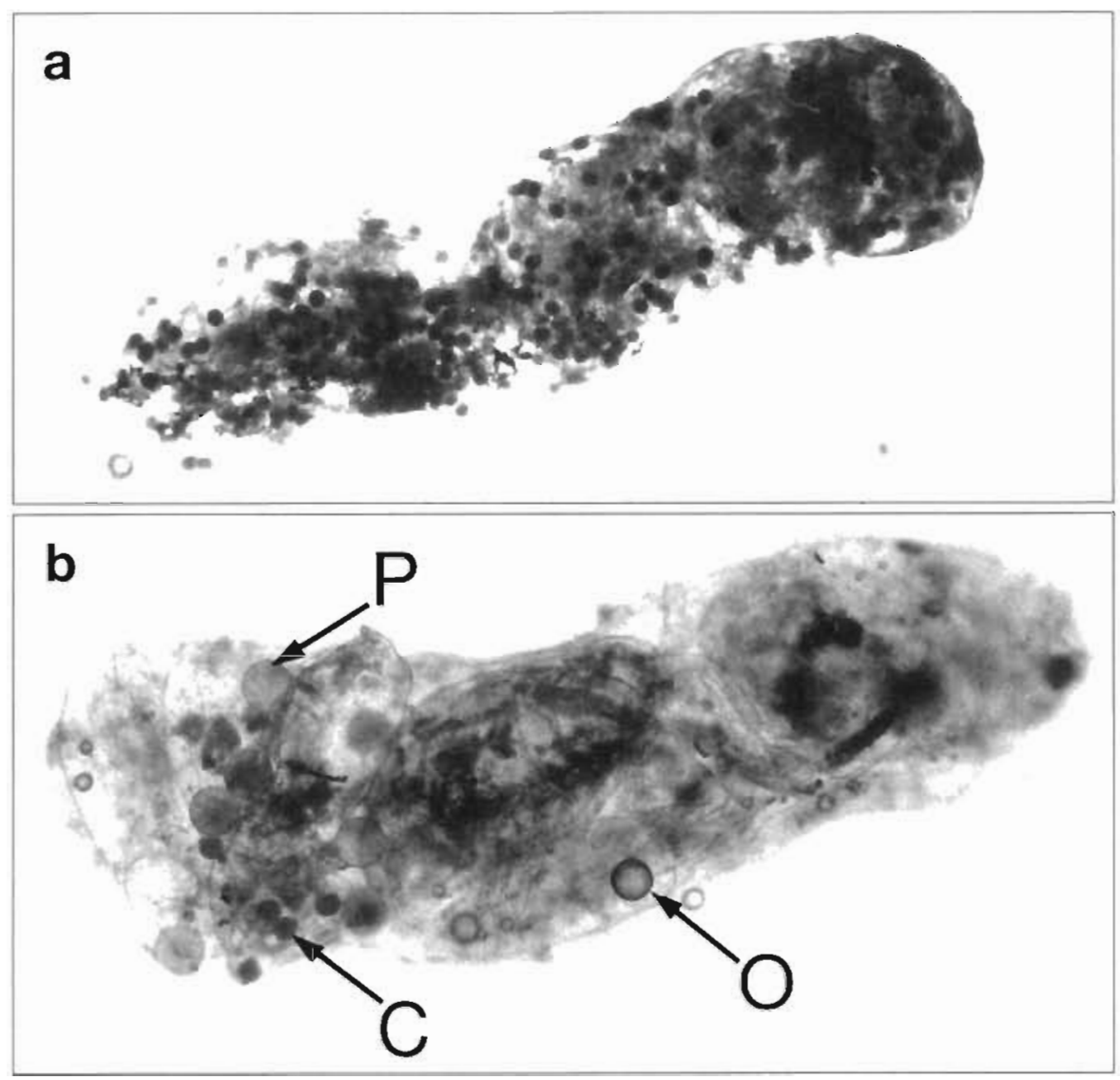

per female in the faeces was closer to the fresh value than for any of the other species. The wide variations observed in gut passage time of copepods may have been due to fluctuations, between collections, in the size structure of the mixed, natural zooplankton supplied as food, since larger food organisms pass through the intestinal tracts of larval fish slower than smaller ones (Karjalainen et al. 1991).

There was no evidence that the considerable discrepancy in number of eggs per female copepod in the faeces compared with the number carried by females before ingestion, for Pseudocalanus elongatus and to a lesser extent Corycaeus anglicus and other species, was due to the eggs being digested, but may arise from them being discarded or separated from females during capture and ingestion, which particularly appeared to be the case in $P$. elongatus. In addition, the faeces break off as they are produced and eggs may be lost from the open ends.

There are periods during copepod egg development when they may be especially susceptible to digestion, particularly when they are first extruded. In Calanus helgolandicus the egg emerges from the genital pore like a drop of fluid and within $5 \mathrm{~min}$, once membranes develop, becomes round (Marshall \& Orr 1955, authors' pers. obs.). A similar process has been described in Pseudocalanus elongatus (Corkett \& McLaren 1978). Eurytemora velox eggs may be extruded at a more advanced stage of encapsulation compared to the species above, as when observed within the oviducts were already spherical. It has also been suggested that late development eggs may be more vulnerable to digestion due to osmotic effects of digestive fluids causing nauplii to be liberated (Redden \& Daborn 1991)

Copepod egg membranes are considered to be largely composed of chitin (Marshall \& Orr 1954), which is not, at least substantially, digested by larval fish (Conway et al. 1993). As the egg membranes form an unbroken barrier, enzyme penetration must depend on enzymatic or mechanical disruption. Kono et al. (1987) demonstrated chitinolytic enzyme activity in egg and larval stages of sea bream Pagrus major and Lindsay (1985) from the late yolk-sac stage onwards in trout Salmo gairdneri, although the importance of its role in digestion has yet to be established. The tough outer membrane of eggs and their spherical shape renders them relatively resistant to mechanical disruption, though some fish larvae, such as mackerel Scomber scomber, have a well developed set of teeth on the 
jaws and develop teeth from an early age (Russell 1976), which could be used to puncture food. One of the few reports of fish larvae disrupting their prey during ingestion was in Coregonus lavaretus (Rösch \& Segner 1990).

Eggs can form on average $29 \%$ of the dry weight biomass of adult female Eurytemora velox (Conway et al. 1993) and 13 to $53 \%$ for E. herdmanni (Crawford \& Daborn 1986) so non-digestion of eggs can represent a considerable loss of potentially valuable food. Fish larvae which cannot digest the eggs of ingested eggcarrying copepods will still obtain nutrition from the copepod. However, it is of great interest to know if first feeding larvae, whose limited swimming ability and jaw gape restricts them to easily caught small prey, are able to digest eggs of copepods which are freespawned, such as Calanus helgolandicus and $C$. finmarchicus. These species can dominate the copepod zooplankton biomass in the North Atlantic region (Williams \& Conway 1988) and in some areas their large eggs (approximately 140 to $180 \mu \mathrm{m}$ ) can be a major primary food source in the diet of early larval fish, often of important commercial species (Bainbridge \& McKay 1968, Bjørke 1978, Conway 1980, Kane 1984, Economou 1991). Survival and recruitment of these larvae could be influenced if they were unable to digest copepod eggs.

From gut content analysis of early larval ( 3 to $7 \mathrm{~mm}$ ) blue whiting Micromesistius poutassou, the diet comprised by number $29 \%$ Calanus finmarchicus eggs (Conway 1980), the majority showing no evidence of digestion. In contrast there are several reports, from a range of larval fish species including cod Gadus morhua and haddock Melanogrammus aeglefinus (Kane 1984), redfish Sebastes spp. (Bainbridge \& McKay 1968) and herring Clupea harengus (Bjørke 1978), detailing observations on digestion of Calanus spp. eggs. It is possible that only certain fish larvae can digest copepod eggs and perhaps only from particular species.

There was a range of viability of fresh eggs between copepod species. This was not large between most species ( 84.8 to $95.4 \%$ ), apart from Euterpina acutifrons (68.6\%). The low viability in $E$. acutifrons does not necessarily mean that the eggs had not been fertilized, since large seasonal fluctuations in individual copepod species hatching success can occur (Ianora et al. 1992). The response of eggs to digestive action, as measured by their viability on egestion, separated the copepods into 2 groups. Eggs of E. acutifrons, Eurytemora affinis and Eurytemora velox retained a high viability, similar to results obtained by Redden \& Daborn (1991) derived from feeding experiments on Eurytemora herdmanni. The viabilities measured for Pseudocalanus elongatus, Oncaea venusta and Corycaeus anglicus eggs showed they are considerably less resistant. It was clear by the appearance of $P$. elongatus eggs on egestion that the high loss of viability in this species was because cells of most eggs were being disrupted by digestive action, while the egg membrane remained intact and the contents apparently not removed.

The reasons for the interspecific variation in egg viability following gut passage are not known, but are presumably related to a combination of differences in the structural composition of the egg membranes and osmotic tolerance of the internal cells. The eggs of the euryhaline species Eurytemora affinis and E. velox may be pre-adapted to surviving the osmotic stress of gut passage because of their wide salinity tolerance. Eggs of Temora longicornis and Acartia clausi may also be adapted to withstand environmental stress. These species have been shown to produce resting, as opposed to diapause, eggs, which remained viable within bottom sediments and still hatched after a year (Lindley 1990). Lindley (1992) found differences between formalin preserved eggs of Acartia and Temora spp. and those of Pseudocalanus and Calanus spp. Eggs of the former 2 species did not take up stain and also did not respond as conspicuously to osmotic stress as the latter 2 species, suggesting differences between them in the structure of the egg membranes.

Retention of a high viability in egested eggs of some of the copepod species has implications for copepod survival, since egg-carrying species have been shown to be selected by fish larvae, the eggs increasing their profile and hence vulnerability (Bollens \& Frost 1991). However, an unknown proportion of nauplii from hatching of faecal eggs may not escape the faeces. The proportion escaping will depend on how rapidly the faecal membrane breaks down under natural conditions. Faeces probably sink very rapidly, as has been shown for adult fish faeces (Robison \& Bailey 1981), and many nauplii may not survive.

Acknowledgements. We thank A. Barbour and W. Cleeve of Golden Sea Produce Ltd for supplying experimental material, D. J. Lesley for provision of phytoplankton cultures, P. H. Bramhall for carrying out initial trial experiments and S. H Coombs for helpful comments on the manuscript. Finance for this study has been provided in part by the U.K. Ministry of Agriculture Fisheries and Food (MAFF) under contract GCA 10, and by the U.K. Department of the Environment (DoE) under contract PECD 7/7/359.

\section{LITERATURE CITED}

Alvarez-Cadena, J. N. (1993). Feeding of the chaetognath Sagitta elegans Verrill. Estuar. coast. Shelf Sci. 36: 195-206

Bainbridge, V., McKay, B. J. (1968). The feeding of cod and redfish larvae. Spec. Publs int. Commn NW Atlant. Fish. 7 : $187-217$ 
Ban, S., Minoda, T (1991). The effect of temperature on the development and hatching of diapause and subitaneous eggs in Eurytemora affinis (Copepoda: Calanoida) in Lake Ohnuma, Hokkaido, Japan. Bull. Plankton Soc. Japan Spec. Vol.: 299-308

Bennett, H. S., Wyrick, A. D., Lee, S. W., McNeil, J. H. (1976) Science and art in preparing tissues embedded in plastic for light microscopy, with special reference to glycol methacrylate, glass knives and simple stains. Stain Technol. 51: $71-97$

Bjørke, H. (1978). Food and feeding of young herring larvae of Norwegian spring spawners. FiskDir. Ser. Havunders. 16 405-421

Bollens, S. M., Frost, B. W. (1991). Ovigerity, selective predation, and variable diel vertical migration in Euchaeta elongata (Copepoda: Calanoida). Oecologia 87: 155-161

Champeau, A. (1970). Etude de la vie latente chez les Calanoïdes (Copépodes) caractéristiques des eaux temporaires de Basse-Provence. Annls Fac. Sci. Marseille 44: $155-189$

Conway, D. V P. (1980). The food of larval blue whiting, Micromesistius poutassou (Risso), in the Rockall area. J. Fish. Biol. 16: 709-723

Conway, D. V. P., Tranter, P. R. G., Coombs, S. H. (1993). Digestion of natural food by larval and post-larval turbot Scophthalmus maximus. Mar. Ecol. Prog. Ser. 100: $221-231$

Conway, D. V. P., Tranter, P. R. G., Fernandez de Puelles, M. L., Coombs, S. H. (1991). Feeding of larval sprat (Sprattus sprattus L.) and sardine (Sardina pilchardus Walbaum). Comm. Meet. int. Coun. Explor. Sea C.M.-ICES 1991/L: 76: 1-15

Corkett, C. J., McLaren, I. A. (1978). The biology of Pseudocalanus. Adv. mar. Biol. 15: 1-231

Crawford, P., Daborn, G. R. (1986). Seasonal variations in body size and fecundity in a copepod of turbid estuaries. Estuaries 9: 133-141

Economou, A. N. (1991). Food and feeding ecology of five gadoid larvae in the northern North Sea. J. Cons. int. Explor. Mer 47: 339-351

Ianora, A. Mazzocchi, M. G., Grottoli, R. (1992). Seasonal fluctuations in fecundity and hatching success in the planktonic copepod Centropages typicus. J. Plankton Res. 14 $1483-1494$

Kane, J. (1984). The feeding habits of co-occurring cod and haddock larvae from Georges Bank. Mar. Ecol. Prog. Ser. 16: $9-20$

Karjalainen, J., Koho, J., Viljanen, M. (1991). The gastric evacuation rate of vendace (Coregonus albula L.) larvae predating on zooplankters in the laboratory. Aquaculture 96: $343-35$

Kellerman, A. (1990). Food and feeding dynamics of the larval Antarctic fish Notothenopsis larseni. Mar. Biol. 106: $159-167$

Kono, M., Furukawa, K., Satoh, H., Matsui, T., Shimizu, C. (1987). Changes in the chitinase activity at different stages of red sea bream Pagrus major egg, larva, and juvenile.

This note was submitted to the editor
Nippon Suisan Gakk. 53: 1289-1293

Lindley, J. A. (1990). Distribution of overwintering calanoid copepod eggs in sea-bed sediments around southern Britain. Mar. Biol. 104: 209-217

Lindley, J A. (1992). Resistant eggs of the Centropagoidea (Copepoda: Calanoida): a possible preadaption to colonization of inland waters. J. Crust. Biol. 12: 368-371

Lindsay, G. J. H. (1985). Development of gastric chitinase activity in trout (Salmo gairdneri). Aquaculture 48 $285-290$

Marcus, N. H. (1984). Recruitment of copepod nauplii into the plankton: importance of diapause eggs and benthic processes. Mar. Ecol. Prog. Ser. 15: 47-54

Marshall, S. M., Orr, A. P. (1954). Hatching in Calanus finmarchicus and some other copepods. J. mar. biol. Ass. U.K. 33: 393-401

Marshall, S. M., Orr, A. P. (1955). The biology of a marine copepod. Oliver \& Boyd, Edinburgh

McFadzen, I. R. B., Lowe, D. M., Coombs, S. H. (in press). Histological changes in starved turbot larvae (Scophthalmus maximus) quantified by digital image analysis. J. Fish Biol.

Nakata, K. (1988). Alimentary tract contents and feeding conditions of ocean-caught post-larval Japanese sardine, Sardinops melanostictus. Bull. Tokai Reg. Fish. Res. Lab. 126: $11-24$

Proctor, V. W., Malone, C. R., DeVlaming, V. L. (1967). Dispersal of aquatic organisms: viability of disseminules recovered from the intestinal tract of captive killdeer. Ecology 48: 672-676

Redden, A. M., Daborn, G. R. (1991). Viability of subitaneous copepod eggs following fish predation on egg-carrying calanoids. Mar. Ecol. Prog. Ser. 77: 307-310

Robison, B. H., Bailey, T. G. (1981). Sinking rates and dissolution of midwater fish fecal matter Mar. Biol. 65: 135-142

Rösch, R., Segner, H. (1990). Development of dry food for larvae of Coregonus lavaretus L. 1. Growth, food digestion and fat absorbtion. Aquaculture 91: 101-115

Russell, F. S. (1976). The eggs and planktonic stages of British marine fishes. Academic Press, London

Schnack, D. (1972). Nahrungsökologische Untersuchungen an Heringslarven. Ber. dt. wiss. Kommn Meeresforsch. 22: $273-343$

Tully, O., O Céidigh, P. (1989). The ichthyoneuston of Galway Bay (west of Ireland). II. Food of post-larval and juvenile neustonic and pseudoneustonic fish. Mar. Ecol. Prog. Ser. 51. $301-310$

Viñas, M. D. (1991). Feeding ecology of Engraulis anchoita first feeding larvae in a tidal mixed front off the Valdes Peninsula (Argentina). Comm. Meet. int. Coun. Explor. Sea C.M.-ICES 1991/L: 83: 1-19

Williams, R., Conway, D. V. P. (1988). Vertical distribution and seasonal numerical abundance of the Calanidae in oceanic waters to the south-west of the British Isles. Hydrobiologia 167/168: 259-266

Zismann, L., Berdugo, V., Kimor, B. (1975). The food and feeding habits of early stages of grey mullets in the Haifa Bay region. Aquaculture 6: 59-75

Manuscript first received: December 8, 1993

Revised version accepted: January 25, 1994 